\title{
In vitro germination and development of two endangered endemic Colombian orchids Cattleya mendelii and Cattleya quadricolor
}

\section{Germinación y desarrollo in vitro de dos orquídeas amenazadas endémicas de Colombia, Cattleya mendelii y Cattleya quadricolor}

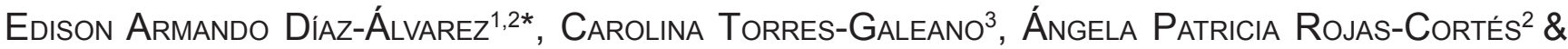 \\ ERICK DE LA BARRERA ${ }^{1}$
}

${ }^{1}$ Instituto de Investigaciones en Ecosistemas y Sustentabilidad, Universidad Nacional Autónoma de México, Morelia, Michoacán C.P. 58190, México.

${ }^{2}$ Posgrado en Ciencias Biológicas, Universidad Nacional Autónoma de México, Ciudad Universitaria, México, Distrito Federal C.P. 04510 , México.

3Universidad Sergio Arboleda, Calle 74 Nº 14-14, Bogotá C.P. 110221, Colombia.

*ealvarez@cieco.unam.mx

\begin{abstract}
Cattleya mendelii and C. quadricolor are endemic orchids from Colombia, which have been subjected to extraction from their natural environments for commercial purposes, becoming critically endangered. However, there is no sustainable management practice for the conservation of these species. The aim of this study was to establish a protocol of in vitro culture for both species. The effects of different combinations of $\mathrm{GA}_{3}$ and NAA amending MS and KC culture media were assessed for the in vitro germination and plant growth. Plant development was assessed monthly over 120 days. A higher percentage of explant production for both species was observed with MS than KC. The higher GA 3 proportion of $1.5 \mu \mathrm{M}$ resulted in enhanced germination, while the higher NAA concentration of $1.5 \mu \mathrm{M}$ favored later stages of plant development. For instance, the number of roots and the length of roots and shoots were higher under incubation on MS that under $\mathrm{KC}$ for both species. In vitro germination for C. mendelii and for C. quadricolor was successful for their propagation and could be useful in future conservation programs for these species.
\end{abstract}

KEYwords: Biotechnology, conservation, culture media, growth regulators, plant development.

\begin{abstract}
RESUMEN
Cattleya mendelii y C. quadricolor son dos orquídeas endémicas de Colombia que han sido sujetas a extracción de sus ambientes naturales para la venta, esto ha conducido a estas plantas a estar críticamente amenazadas. En la actualidad, no existe una práctica sustentable para el manejo de estas especies. El objetivo de este estudio fue establecer un protocolo de cultivo in vitro para ambas especies. El efecto de diferentes combinaciones de medios de cultivo MS y KC modificados con $\mathrm{AG}_{3}$ y ANA fueron evaluados para la germinación y desarrollo in vitro. El desarrollo fue evaluado cada 30 días, durante 120 días. La mayor producción de explantes para ambas especies fue observada con MS. Mayor proporción de $\mathrm{AG}_{3}$ de 1.5 $\mu \mathrm{M}$ resultó en el aumento de la germinación, asimismo mayores concentraciones de ANA de $1.5 \mu \mathrm{M}$ favorecen los estadios tardíos del desarrollo vegetal in vitro. El número y la longitud de los brotes y las raíces fueron mayores cuando las plantas de ambas especies se cultivaron en medio MS. La germinación y desarrollo in vitro de C. mendelii and C. quadricolor en este estudio fue una aproximación exitosa para la propagación y puede ser considerada para programas de conservación de estas orquídeas.
\end{abstract}

Palabras clave: Biotecnología, conservación, desarrollo vegetal, medios de cultivo, reguladores del crecimiento vegetal.

\section{INTRODUCTION}

The genus Cattleya (Orchidaceae), native to Central and South America, occurs along mountain ranges, dry forests, and the transition to wet and cloudy hillsides and canyons, mainly on trees and rocks (Calderón 2007). Cattleya mendelii Dombrain and C. quadricolor Lindl. are endemic to Colombia and have been traditionally kept in home gardens owing to their beautiful flowers. Additionally, the over-extraction from their habitat for sale at local and international markets has 
led to an $80 \%$ reduction of their wild populations over the last century. As a result, these orchids have been recognized by the International Union for Conservation of Nature as a critically endangered species (Calderón 2007).

To date, there is no a sustainable management practice for these species of endangered orchids. In this respect, the in vitro propagation of vascular plants is a useful method that can be utilized for commercial or for conservation purposes as an alternative that might help in decreasing the extractive pressure on natural populations of endangered plants (Rubluo et al. 1993, Arditti \& Krikorian 1996, Buyun et al. 2004, Lo et al. 2004, Santos-Hernández et al. 2005, Ávila-Díaz et al. 2009). However, the in vitro propagation of orchids requires a species-specific method for massive and rapid production of these plants (Arditti 1977, Colli \& Kerbauy 1993, Shimura \& Koda 2003).

Not only the form of nitrogen provided to the culture media but also the presence and concentration of some growth regulators can affect the rate of emergence and development of orchid seeds during in vitro culture (Ichihashi 1992, Chen et al. 2000, Park et al. 2002, Jawan et al. 2010). In consequence, medium optimization, which is a rapid approach for developing propagation protocols, can be useful for the massive production of these endangered Cattleya species. For these reasons, the aim of this study was to evaluate the effects of two culture media MS and $\mathrm{KC}$, in combination with different concentrations of plant growth regulators NAA and $\mathrm{GA}_{3}$ on in vitro germination and development of Cattleya mendelii and C. quadricolor, to establish a protocol for the in vitro propagation of both species to aid in their conservation.

\section{MATERIALS AND METHODS}

\section{Plant material and establishment of IN VItro CUlture}

Closed capsules of Cattleya mendelii and C. quadricolor were obtained from the commercial nursery (Las Orquídeas, San Antonio del Tequendama, Colombia, 4 $34^{\prime} 17^{\prime \prime} \mathrm{N}, 7^{\circ}$ 18 ' 45" W; 2000 masl), where the parental plants had been selected and cross pollinated by hand for this study. When the capsules started to turn yellow, they were harvested with sterile garden shears and transported to the in vitro culture laboratory of the Fundación Zoológico Santa Cruz, where they were kept during 1 day in the laminar flow hood until the start of the experiment.

While in the laminar flow hood, the capsules were disinfected by immersion in $90 \%$ ethanol ( $\mathrm{v} / \mathrm{v}$ ) for five minutes, rinsed with sterile distilled water, and submerged in 5\% sodium hypochlorite for $20 \mathrm{~min}$, and rinsed with sterile distilled water. Each capsule was longitudinally dissected in a sterile Petri dish, where approximately half of the seeds were suspended in $70 \mathrm{~mL}$ of sterile distilled water. After shaking the seed suspension with a vortex, an aliquot of 1
$\mathrm{mL}$, which contained ca. 50 seeds were placed uniformly in glass bottles containing the experimental culture medium.

\section{EXPERIMENTAL TREATMENTS}

Seed germination and seedling development were evaluated by planting the seeds in either KC (Knudson 1946) or MS (Murashige \& Skoog 1962) culture media enriched with sucrose $(30 \mathrm{~g} / \mathrm{L})$ and experimentally amended with various combinations of giberelic acid $\left(\mathrm{GA}_{3}\right)$ and naphthaleneacetic acid (NAA): $0 / 0 ; 0.5 / 1.5 ; 1.0 / 1.0 ; 1.5 / 0.5 \mu \mathrm{M}$ respectively. For each experimental treatment, $25 \mathrm{~mL}$ of growth medium were added to a glass bottle of $120 \mathrm{~mL}$ in volume, in which the seeds were planted as described above.

The glass bottles were placed in a tissue culture room at $22 \pm 2{ }^{\circ} \mathrm{C}$ and a photoperiod of $12 \mathrm{~h}$. Plant development was evaluated every 30 days and the number of individuals at the various stages were recorded as follows: germination (defined as the stage when the embryo emerges from the integument) at 30 days, protocorm-like bodies (the embryo is completely released from integument) at 60 days, shoots (the protocorm is differentiated) at 90 days, and seedlings (emergence of leaf blades, rhizomes) were recorded at 120 days.

After 120 days of culture the number of roots was counted and leaf and root length were measured with a vernier caliper (readable to 0.02 millimeters). The number of leaves was not counted because for these species the maximum number of leaves is fixed to one or two and does not respond to treatments at 120 days of in vitro culture (unpublished observations).

\section{DATA ANALYSIS}

Data were analyzed under a factorial arrangement according to a fully randomized design. For each species, the stage of development and seedling growth were compared among medium and hormone treatment with two way ANOVAs followed by a post hoc Holm Sidak test (at $p<0.05$ ). All analyses were conducted with Sigmastat 3.5 (Systat ${ }^{\circledR}$, Richmond California, USA). Data are shown as means \pm 1 S.E. for 10 glass bottles containing 50 seeds each that were prepared as described above.

\section{RESULTS}

\section{CATTLEYA MENDELII}

For $C$. mendelii the MS medium promoted a higher seed germination than the KC medium (Table I; Fig. 1a). At 30 days of incubation, the highest germination rate of 95.2 $\pm 0.8 \%$ was observed for seeds grown on MS medium amended with $1.5 \mu \mathrm{M}$ of $\mathrm{GA}_{3}$ and $0.5 \mu \mathrm{M}$ of NAA, while the lowest germination of $41.7 \pm 1.2 \%$ was recorded for seeds incubated with no growth regulator enrichment in $\mathrm{KC}$ medium (Fig. 1a). 
At 60 days of incubation, $C$. mendelii had the highest protocorm development when grown on MS than on $\mathrm{KC}$ (Table I; Fig. 1b). In particular, the highest survival at this stage of development, $94.6 \pm 0.8 \%$, was observed for plants growing in $\mathrm{MS}$ amended with $1.0 \mu \mathrm{M} \mathrm{GA}$ and $1.0 \mu \mathrm{M}$ NAA, while the lowest survival was recorded for plants incubated in $\mathrm{KC}$ without growth regulator enrichment.

At 90 days of incubation, a significant interaction was found between the medium and the growth regulator amendment for shoot yield of both orchids (Table I; Fig 1c). In particular, for $C$. mendelii the highest percentage of surviving plants with shoots was $97.1 \pm 0.6 \%$ observed for individuals growing in MS amended with $0.5 \mu \mathrm{M} \mathrm{GA}_{3}$ and $1.5 \mu \mathrm{M}$ NAA.

At 120 days of incubation a greater seedling survival was observed for $C$. mendelii growing on MS than on KC (Table I; Fig. 1d). In particular, the highest seedling survival of $95.9 \pm 0.9 \%$ was observed under incubation with MS amended with $0.5 \mu \mathrm{M} \mathrm{GA}_{3}$ and $1.5 \mu \mathrm{M}$ NAA, while the lowest survival of $60.3 \pm 1.0 \%$ was recorded under incubation with $\mathrm{KC}$ with no growth regulator amendment.

Leaf length for $C$. mendelii was affected by the culture medium utilized (Table I; Fig. 2a). For individuals incubated in MS amended with $0.5 \mu \mathrm{M} \mathrm{GA}_{3}$ and $1.5 \mu \mathrm{M}$ NAA, a leaf length of $11.1 \pm 0.5 \mathrm{~mm}$ and the presence of $4.1 \pm 0.4$ roots per plant with an average length of $9.6 \pm 0.5 \mathrm{~mm}$, were consistently higher than for plants incubated with other culture media (Fig 2b, c). Contrasting was the case of plants incubated with no hormonal enrichment in MS whose leaf length and root number and length only amounted to 5.0, 2.4 , and $4.4 \mathrm{~mm}$ respectively.

\section{CATTLEYA QUADRICOLOR}

C. quadricolor showed significant differences on seed germination among the growth media (Table I; Fig. 1e). At 30 days of incubation, the highest germination of $84.3 \pm$ $1.1 \%$ for seeds incubated in $\mathrm{KC}$ and $96.4 \pm 0.6 \%$ in MS was observed for seeds incubated with $1.5 \mu \mathrm{M}$ of $\mathrm{GA}_{3}$ and $0.5 \mu \mathrm{M}$ of NAA. The lowest germination of $54.2 \pm 1.1 \%$ in $\mathrm{KC}$ and $59.3 \pm 1.0 \%$ in MS medium was recorded for seeds incubated with no growth regulator amendment.

Statistical differences on protocorm survival were observed for $C$. quadricolor plants growing on either incubation medium (Table I; Fig. 1f). The highest protocorm survival of $95.7 \pm 0.7 \%$ for plants grown in MS enriched with $0.5 \mu \mathrm{M} \mathrm{GA}_{3}$ and $1.5 \mu \mathrm{M}$ NAA. The lowest protocorm survival for $C$. quadricolor was recorded for plants grown on either medium without growth regulator amended.

The lowest yield of shoots for $C$. mendelii at 90 days of incubation was observed for plants grown in $\mathrm{KC}$ without growth regulators yielded $52.0 \pm 0.8 \%$. For $C$. quadricolor, the highest yield of $95.6 \pm 1.1 \%$ was observed for plants incubated with MS amended with $0.5 \mu \mathrm{M} \mathrm{GA}$ and 1.5 $\mu \mathrm{M}$ NAA. The lowest yield of shoots of $62.9 \pm 1.1 \%$ was observed in MS amended with $1.5 \mu \mathrm{M} \mathrm{GA}_{3}$ and $0.5 \mu \mathrm{M}$ NAA.

Significant interaction was found between culture medium and growth regulator amendment for seedling survival of C. quadricolor (Table I; Fig 1h). The highest seedling survival of $94.4 \pm 1.0 \%$ was recorded for plants incubated in MS enriched with $0.5 \mu \mathrm{M} \mathrm{GA}$ and $1.5 \mu \mathrm{M}$ NAA, while the lowest seedling survival of $64.5 \pm 3.5 \%$ was observed for plants incubated in $\mathrm{KC}$ with no growth regulator amendment.

Seedling growth for this species was enhanced by the incubation in MS (Table I). Leaf length ranged from 5.1 $\pm 0.41 \mathrm{~mm}$ for plants incubated in either medium without hormonal amended to $10.2 \pm 0.4 \mathrm{~mm}$ for seedlings grown in MS amended with $0.5 \mu \mathrm{M} \mathrm{GA}_{3}$ and $1.5 \mu \mathrm{M}$ NAA (Fig. 2d). The highest count of $4.2 \pm 0.3$ roots per plant was found for plants incubated with MS amended with $0.5 \mu \mathrm{M} \mathrm{GA}$ and $1.5 \mu \mathrm{M}$ NAA and $\mathrm{KC}$ amended with $1.0 \mu \mathrm{M} \mathrm{GA}_{3}$ and 1.0 $\mu \mathrm{M}$ NAA (Fig. 2e). The lowest root number of $2.0 \pm 0.3$ was found for plants incubated in MS medium without hormonal amendment. Root length for seedlings of $C$. quadricolor averaged $8.9 \pm 0.3 \mathrm{~mm}$ in $\mathrm{KC}$ and $9.2 \pm 0.4 \mathrm{~mm}$ in $\mathrm{MS}$ medium with hormonal amended (Fig. 2f). It decreased by $33.7 \%$ for seedlings incubated in MS medium without hormonal amendment and by $51.7 \%$ for seedlings incubated in $\mathrm{KC}$ medium without hormonal amended.

\section{DISCUSSION}

While a high germination percentage was observed for both Cattleya mendelii and C. quadricolor under all treatments, MS was the best medium for this and all subsequent developmental stages. For germination, MS was best in combination with $1.5 \mu \mathrm{M} \mathrm{GA}_{3}$ and $0.5 \mu \mathrm{M}$ NAA, while for the remaining stages $\mathrm{MS}$ amended with $0.5 \mu \mathrm{M} \mathrm{GA}$ and $1.5 \mu \mathrm{M}$ NAA yielded higher survival. An exception was protocorm development for $C$. mendelii, whose largest number was observed for plants incubated in $1.0 \mu \mathrm{M} \mathrm{GA}$ and 1.0 $\mu \mathrm{M}$ NAA in MS medium. Additionally, $\mathrm{KC}$ and MS were equally effective for leaf and root growth, as well as for root number of $C$. mendelii when amended with 0.5 $\mu \mathrm{M} \mathrm{GA}_{3}$ and $1.5 \mu \mathrm{M}$ NAA for $C$. quadricolor. KC and MS media amended with $0.5 \mu \mathrm{M} \mathrm{GA}_{3}$ and $1.5 \mu \mathrm{M}$ NAA, showed differences in root number and leaf length.

Ammonium salts yield better in vitro growth than nitrates (Raghavan \& Torrey 1964, Hew \& Yong 2004). Seeds respond directly to the concentration of ammonium nitrate in the medium. For instance, when seeds germinate in a medium lacking $\mathrm{NH}_{4}$, small protocorms are formed and further growth is suppressed (Raghavan \& Torrey 1964, Kauth et al. 2008). Here, MS was a better culture medium for both species of Cattleya because its composition that includes ammonium nitrate provides the same proportion 


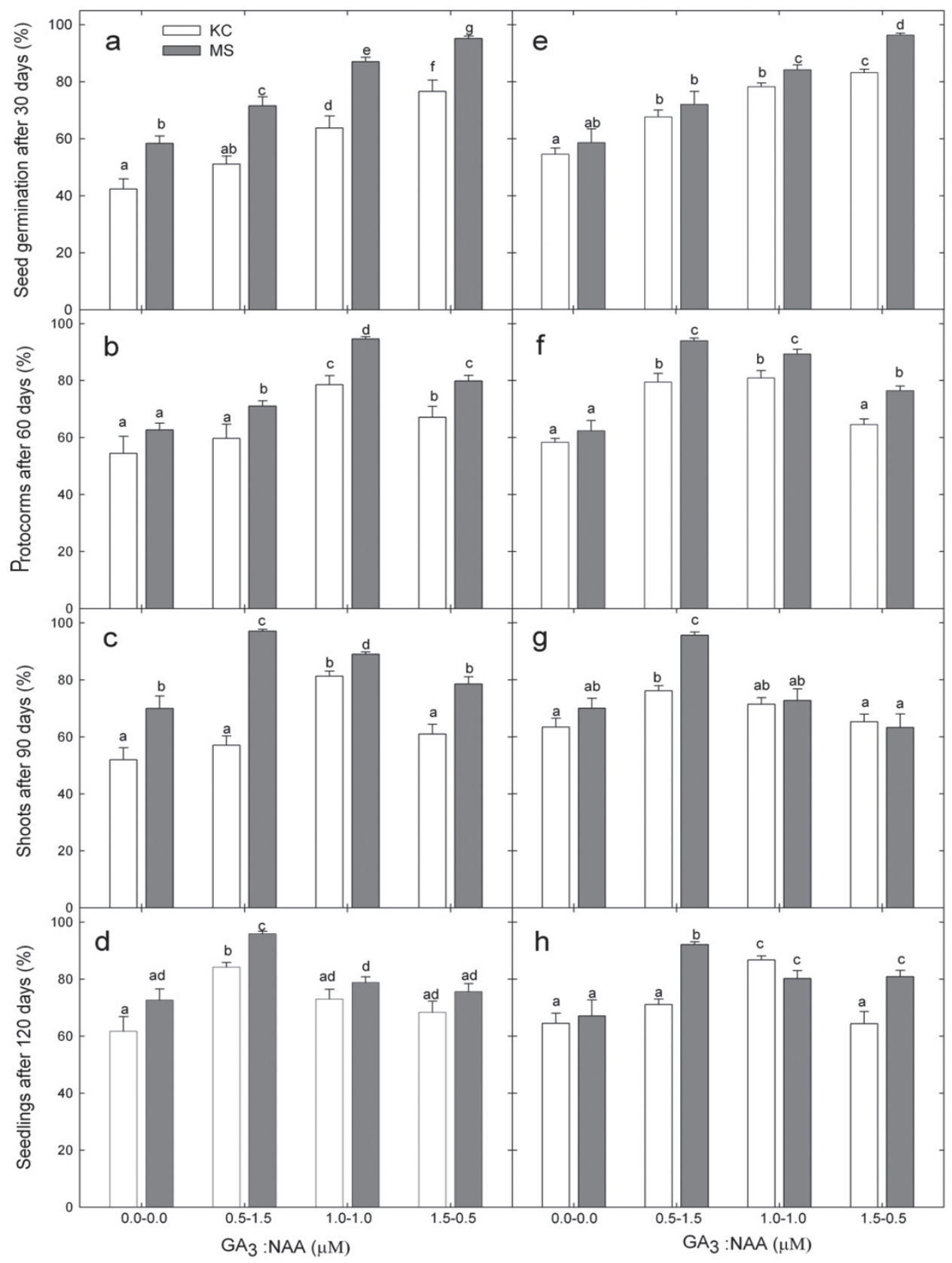

FIGURE 1. Survival for Cattleya mendelii (a-d) and C. quadricolor (e-h) at various developmental stages growing on KC (Knudson 1946; white bars) and MS (Murashige \& Skoog 1962; grey bars) amended with various concentrations of GA and NAA. Seeds that germinated (a, e) were counted at 30 days of incubation, while protocorms (b, f), were counted at 60 days of incubation. Shoots (c, g) were counted at 90 days of incubation and the ensuing seedlings $(\mathrm{d}, \mathrm{h})$ at 120 days of culture. Data are shown as mean \pm S.E. (n $=10$ glass bottles containing ca. 50 seeds each). For each panel, different letters indicate a statistical difference $(p<0.05)$ from Holm-Sidak test following 2-way ANOVAs.

Figura 1. Sobrevivencia de Cattleya mendelii (a-d) y C. quadricolor (e-h) en distintas etapas del desarrollo incubadas en los medios KC (Knudson 1946; barras blancas) y MS (Murashige \& Skoog 1962; barras grises) enriquecidos con varias concentraciones de GA3 y NAA. Las semillas que germinaron ( $\mathrm{a}, \mathrm{e})$ se contaron a los 30 días de incubación, mientras que los protocormos (b, f) se contaron a los 60 días de incubación. Los brotes (c, g) se contaron a los 90 días de incubación y las plántulas subsecuentes (d, h) a los 120 días de incubación. Se muestran los datos como promedio \pm E.E. $(n=10$ frascos de cultivo con ca. 50 semillas cada uno). Para cada panel, letras distintas indican diferencias estadísticas $(p<0.05)$ de un ANOVA de 2 vías seguido de una prueba de Holm-Sidak. 


\section{C. mendelii}

C. quadricolor

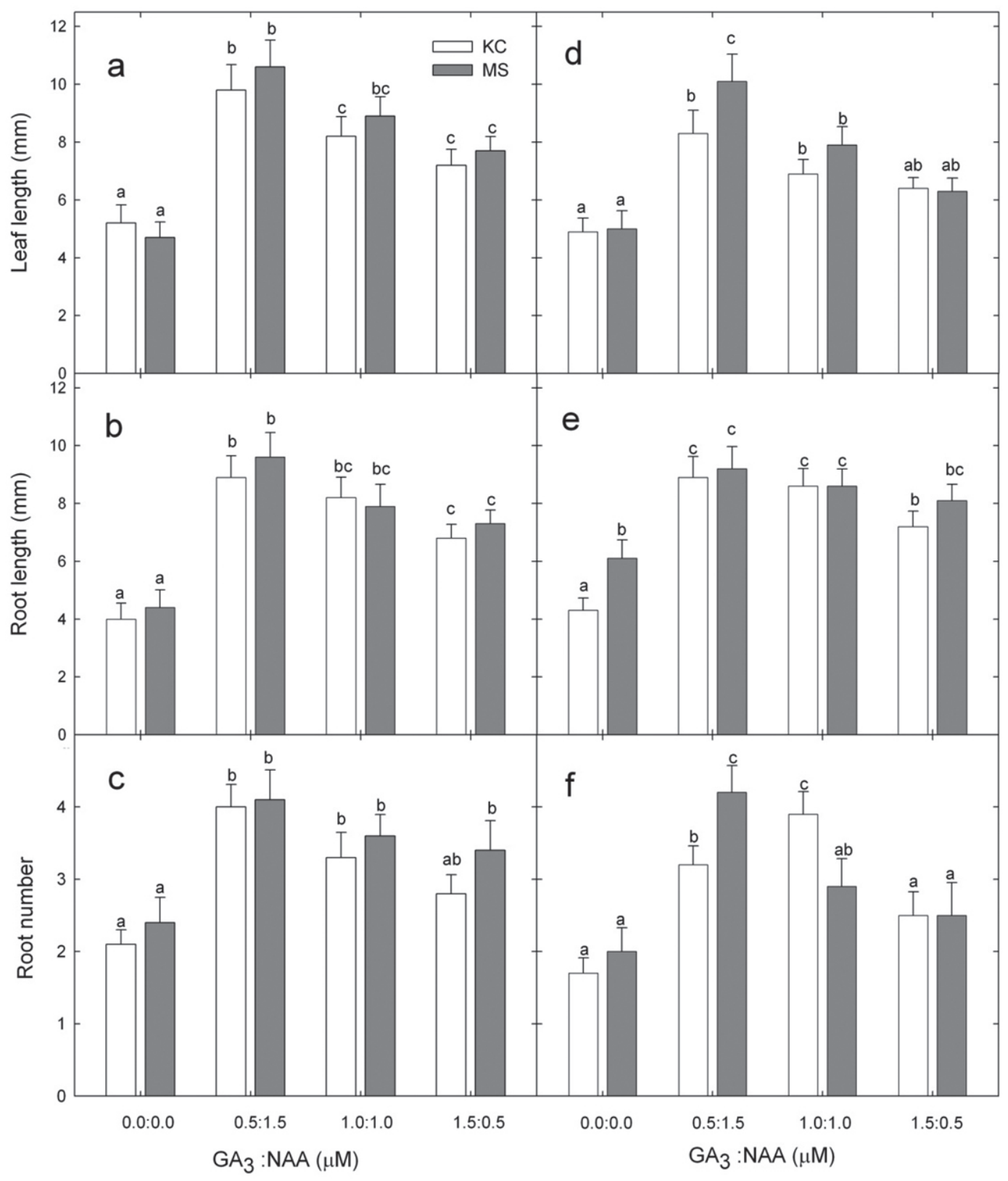

FigurE 2. Seedling growth for C. mendelii (a-c) and C. quadricolor (d-f). Leaf length (a, d), root number (b, e) and root length (c, f) were determined at 120 days of incubation for seedlings growing KC (Knudson 1946; white bars) and MS (Murashige \& Skoog 1962; grey bars) enriched with various concentrations of $\mathrm{GA}_{3}$ and NAA. Data are shown as means \pm S.E. ( $\mathrm{n}=10$ glass bottles containing ca. 50 seeds each). For each panel, different letters indicate a statistical difference $(p<0.05)$ from Holm-Sidak test following 2-way ANOVAs.

Figura 2. Crecimiento de plántulas de C. mendelii (a-c) y C. quadricolor (d-f). La longitud de la hoja (a, d), número (b, e) y longitud (c, f) de raíces se determinaron a los 120 días de incubación para plántulas creciendo en los medios KC (Knudson 1946; barras blancas) y MS (Murashige \& Skoog 1962; barras grises) enriquecidos con distintas concentraciones de GA y NAA. Los datos se muestran como promedio \pm E.E. $(\mathrm{n}=10$ frascos de cultivo con ca. 50 semillas cada uno). Para cada panel, letras distintas indican diferencias estadísticas $(p<0.05)$ de un ANOVA de dos vías seguido de una prueba de Holm-Sidak. 


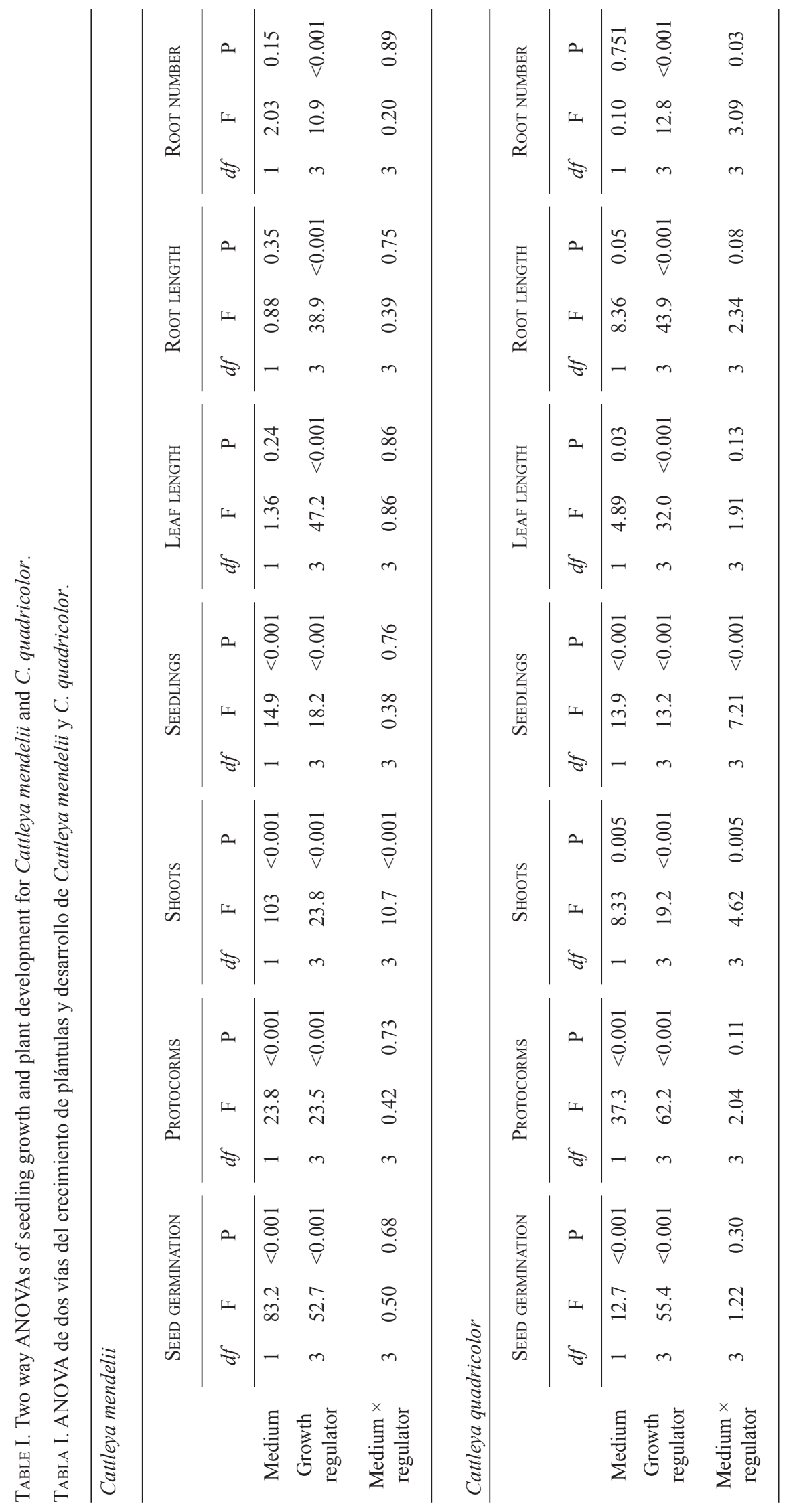


of ammonium and nitrate to seeds (Murashige \& Skoog 1962). In contrast, the KC medium has a higher proportion of nitrate than ammonium (Knudson 1946). In consequence, considering that nitrogen uptake by roots is primarily mediated by the enzyme nitrate reductase, which assimilates nitrates the plants should have responded better to KC. However, the enzyme nitrate reductase is not expressed in orchid tissues until 60 days of in vitro germination making the MS medium better than $\mathrm{KC}$ medium for plants in early stages of development (Hew \& Yong 2004).

Higher $\mathrm{GA}_{3}$ to NAA ratios improved germination for both species incubated in either medium, because the direct effect on in vitro germination by the different $\mathrm{GA}_{3}$ concentrations (Santos-Hernández et al. 2005). This phytohormone activates the $\alpha$-amylase that mediates sugar absorption from the culture medium (Held \& Piechulla, 2010). Thus an ammonium enriched medium such as MS enriched with high concentrations of $\mathrm{GA}_{3}$ can yield very high germination responses as was the case in present work.

The later developmental stages (protocorms, shoots and seedlings) for both orchids, was generally enhanced by a higher proportion of NAA to $\mathrm{GA}_{3}$. This is similar to the developmental responses of Dendrobium species, for which the number of shoots increases in response to the concentration of NAA (Parvin et al. 2009), and for Grammatophyllum speciosum cultivated in a medium enriched with NAA (Sopalun et al. 2010).

A higher proportion of NAA than $\mathrm{GA}_{3}$ produced more and longer roots and longer leaves for both species grown in MS. For another Neotropical orchid, Laelia speciosa, GA produces longer seedlings (Ávila-Díaz et al. 2009). Here, high concentrations of $\mathrm{GA}_{3}$ resulted in shorter leaves and roots than those of plants incubated in medium without this phytohormone.

\section{CONCLUSIONS}

The combination of growth regulators and culture media utilized for the in vitro production of Cattleya mendelii and C. quadricolor from seeds was highly successful in this study, yielding vast number of seedlings of these endangered Colombian orchids. This method can be useful for producing plants for possible reintroductions into natural habitats and for commercial purposes in different markets, in order to decrease the extractive pressure facing natural populations.

\section{ACKNOWLEDGMENTS}

The authors are thankful to Fundación Zoológico Santacruz for technical and financial support.

\section{REFERENCES}

ArditTi, J. 1977. Clonal propagation of orchids by means of tissue culture: A Manual. In: J. Arditti (ed.), Orchid Biology: Reviews and Perspectives I, pp. 203-293. Cornell University Press, New York, USA.

ArditTi, J. \& A.D. Krikorian. 1996. Orchid micropropagation: the path from laboratory to commercialization and an account of several unappreciated investigations. Botanical Journal of the Linnean Society 122: 183-241.

Ávila-Díaz, I., K. Oyama, C. Gómez-Alonso \& R. SalgadoGARCIGLIA. 2009. In vitro propagation of the endangered orchid Laelia speciosa. Plant Cell, Tissue and Organ Culture 99: 335-343.

Buyun, L., A. Lavrentyeva, L. Kovalska \& R. Ivannikov. 2004. In vitro germination of seeds of some rare tropical orchids. Acta Universitatis Latviensis Biology 676: 159-162.

Calderón, S.E. 2007. Libro Rojo de las Plantas de Colombia. Volumen 6. Orquídeas, Primera parte. Serie Libros Rojos de Especies Amenazadas de Colombia. Instituto Alexander von Humboldt Ministerio de Ambiente Vivienda y Desarrollo Territorial, Bogotá. 828 pp.

Chen, Y.C., C. Chang \& W.C. Chang. 2000. A reliable protocol for plant regeneration from callus culture of Phalaenopsis. In Vitro Cellular \& Developmental Biology-Plant 36: 420-423.

Colli, S. \& G.B. Kerbauy. 1993. Direct root tip conversion of Catasetum into Protocorm-Like Bodies. Effect of auxin and cytokinin. Plant Cell, Tissue and Organ Culture 33: $39-44$.

Heldt, H.W. \& B. Piechulla. 2010. Plant Biochemistry, $4^{\text {th }}$ edition. Academic Press, London. 656 pp.

Hew, C. \& J. Yong. 2004. The Physiology of Tropical Orchids in Relation to the Industry, second edition. World Scientific Publishing Co. Pte. Ltd, Singapore. 370 pp.

Ichinashi, S. 1992. Micropropagation of Phalaenopsis through the culture of lateral buds from young flower stalks. Lindleyana 7: 208-215.

JaWAn, J., A.G. Jualang \& O.A. Janna. 2010. In Vitro Culture of Borneo's Endemic Orchid, Vanda dearei. Asian Pacific Journal of Molecular Biology and Biotechnology 18(1): 201-205.

Kauth, P.J., M.E. Kane, A. Wagner, W.A. Vendrame \& C. ReInHARDT-Adams. 2008. Asymbiotic germination response to photoperiod and nutritional media in six populations of Calopogon tuberosus var. tuberosus (Orchidaceae): Evidence for Ecotypic Differentiation. Annals of Botany 102: 783-793.

KNUDSON, L. 1946. A new nutrient solution for orchid seed germination. American Orchid Society Bulletin 15: 214217.

Lo, S.F., S.M. Nalawade, C.L. Kuo, C.L. Chen \& H.S. Tsay. 2004. Asymbiotic germination of immature seeds, plantlet development and ex vitro establishment of plants of Dendrobium tosaense Makino: A medicinally important orchid. In Vitro Cellular \& Developmental BiologyPlant 40: 528-535.

Murashige, T. \& F. Skoog. 1962. A revised medium for rapid growth and bioassays with tobacco tissue cultures. Physiologia Plantarum 15: 473-497. 
Park, S.Y., H.N. Murthy \& K.Y. Paek. 2002. Rapid propagation of Phalaenopsis from flower stalk-derived leaves. In Vitro Cellular \& Developmental Biology-Plant 38: 168-172.

Parvin, M.S., M.E. Haque, F. Akhter, M. Moniruzzaman \& A.B.M. Khaldun. 2009. Effect of different levels of NAA on in vitro growth and development of shoots of Dendrobium orchid. Bangladesh Journal of Agricultural Research 34: 411-416.

RaghaVAn, V. \& J.G. Torrey. 1964. Inorganic and nitrogen nutrition of the seedlings of the orchid Cattleya. American Journal of Botany 51: 264-274.

Rubluo, A., V. Chávez, A.P. Martínez \& O. Martínez-VÁzquez. 1993. Strategies for the recovery of endangered orchids and cacti through in vitro culture. Biological Conservation 63: 163-169.

Santos-Hernández, L., M. Martínez-García, J.E. Campos \& E. AguirRe-LeÓn. 2005. In vitro propagation of Laelia albida (Orchidaceae) for conservation and ornamental purposes in Mexico. Horticultural Science 40: 439-442.

Shimura, H. \& Y. Koda. 2004. Micropropagation of Cypripedium macranthos var. rebunense through protocorm-like bodies derived from mature seed. Plant Cell Tissue and Organ Culture 78: 273-27.

Sopalun, K., K. Thammasiri \& K. IshiKawa. 2010. Micropropagation of the Thai orchid Grammatophyllum speciosum Blume. Plant Cell Tissue and Organ Culture 101: 143-150.

Recibido:03.03.15

Aceptado: 03.09.15 